\title{
THE IMPERIAL STATE AND ITS IMPACT ON THE ROLE AND STATUS OF LOCAL MAGISTRATES AND COUNCILLORS IN THE PROVINCES OF THE EMPIRE
}

\author{
By \\ G.P.BURTON
}

\section{Introduction}

This paper is an essay of interpretation. It is interested in typical political and social practices and developments. As such it brings together a series of substantive topics, namely the spread of Roman citizenship, the acquisition of legal privilege, centrally generated rules for local office-holding, the collection of direct taxes, the maintenance of order and, finally, the local administrative and political role of civic magistrates and councillors, which in modern scholarship are frequently treated in isolation from each other.'

The crucial importance of the roles performed by civic magistrates and councillors for the routine functioning and stability of the imperial state is a commonplace of modern scholarship. So Peter Brunt in a characteristically magisterial dictum claimed that "hardly any class of men rendered more important services to the Roman state than those charged with local government". ${ }^{2}$ We need only to itemise these services to see the basic truth of this claim. First, the process of assessing and, above all, collecting direct taxes (however difficult it is in detail to give a systematic account of this process) was dependent on the active cooperation of the local elites. Secondly, the procedures for dispute-resolution and the maintenance of social order were similarly dependent on the active involvement of the local elites. Each city operated its own local jurisdictional system of limited competence, and in each city and its territory local magistrates were often responsible for the apprehension, detention and preliminary interrogation of individuals accused of those serious crimes over which only Roman governors legitimately exercised jurisdiction. Given the primordial importance of the regular collection of taxes and of the maintenance of order for the routine functioning and stability of the imperial state, the significance of this role played by the local elites can hardly be overstated. Thirdly, some members of the local elites were required occasionally and unquantifiably to act as ambassadors or legal representatives

\footnotetext{
${ }^{1}$ For these reasons the evidence cited in the text and the footnotes is for the purpose of illusration and is not intended to be exhaustive.

${ }^{2}$ P. A. Brunt, 'The Romanization of the local Ruling Classes in the Roman Empire', in Roman Imperial Themes (Oxford 1990), $267 \mathrm{ff}$. at 270.
} 
of their cities before emperors and/or provincial governors. Fourthly, a minority of civic magistrates and councillors were able to expand the social and geographical range of their influence to the provincial level via membership of the provincial council and/or participation in the organisation of the religious ceremonies and social spectacles associated with the celebration of the imperial cult.

Let us assume that this rather crude and simplified overview, which I have just sketched, of the political interrelationship between the imperial state and the civic elites in the provinces is basically correct. What consequences ensued for the character and development of the status and roles of local magistrates and councillors? The rest of this paper raises four problems. First, to what extent in the medium term did the imperial state purposively reward and privilege local magistrates and councillors? Secondly, to what extent were there centrally generated rules which circumscribed and regulated the procedures by which local magistrates and councillors were appointed? Thirdly, to what extent, again in the medium term, did new local institutional mechanisms emerge (or were existing ones reshaped) to mediate the need to collect taxes and to help to maintain order? Fourthly, to what extent did the imperial state and its representatives constrain and influence the exercise by civic magisrates and councillors of their local political and administrative duties?

\section{Rewards: Citizenship and Legal Privilege}

In the republic grants of Roman citizenship had been a classic mechanism for rewarding aliens who had performed important services to the Roman state. This notion of reward continued under imperial rule to be one of the criteria for the grant of Roman citizenship as the Tabula Banasitana so strikingly shows. ${ }^{3}$ It is, of course, one of the many serious deficiencies in our knowledge of the social history of the Roman empire that we can not quantify the dissemination of Roman citizenship during the course of the first and second centuries. Nevertheless we can assert with confidence that members of the local elites were more likely on average to acquire Roman citizenship than the mass of the free population. In the western provinces the widespread grants of Latin status to provincial communities automatically ensured the enfranchisement of families who had gained magisterial office. ${ }^{4}$ For the cities

\footnotetext{
${ }^{3} \mathrm{~J}$. Gascou, Inscriptions antiques du Maroc (Paris 1982), no.94.

${ }^{4}$ But only in those rare communities which acquired the greater Latin status did all civic councillors also automatically gain Roman citizenship.
} 
of the eastern provinces a selection of illustrative data can serve to give some indication both of the extent of the spread of Roman citizenship within civic elites and of the variation of its incidence. For example at Sparta about $20 \%$ of ephors were Roman citizens in the first quarter of the second century, about $40 \%$ later. ${ }^{5}$ At Ephesus unusually detailed lists of membership of the board of kouretes (whom I will here treat as a rough proxy for the Ephesian elite in general) survive. ${ }^{6}$ During the first century forty-nine out of one hundred known members were Roman citizens; in the second century (excluding the reign of Commodus) the proportion rises to sixty out of eighty-nine and for the reign of Commodus alone to sixty-one out of eighty-three. Yet during the same reign at Sidyma in Lycia scarcely any members of the newly established gerousia were Roman citizens, although many were of councillor status. ${ }^{7}$ These figures serve also to emphasise the possible limits of the dissemination of citizenship. Indeed we have only to remember the example of the Lycian millionaire Opramoas, whose social and political influence extended during the first half of the second century far beyond the confines of his native city, to see that there was no automatic correlation between Roman citizenship and political and social power. ${ }^{8}$ Analogously we should note that province by province the geographic distribution of citizenship was seriously uneven. So a recent analysis has emphasised the very restricted spread of citizenship in the provinces of Syria and Arabia. ${ }^{9}$ In short however widespread the dissemination of Roman citizenship became among provincial elites, it never came to function as a status which systematically and generically demarcated them from the mass of the provincial population.

In the context of this paper much more striking than the spread of citizenship were the evolution and elaboration of rules concerning criminal jurisdiction and penalties which generically privileged local councillors and magistrates. ${ }^{10}$ For example decurions and their children were exempt from beating, ${ }^{11}$ decurions (and their parents and children) could not be sentenced to

\footnotetext{
${ }^{5}$ C.Hoet-Van Cauwenberghe, 'Diffusion de la citoyenneté romaine: notes sur les gentilices impériaux en Laconie et en Messénie', in A. Chastagnol, S. Demougin and C.Lepelley (edd.), Splendidissima Civitas (Paris, 1996), $133 \mathrm{ff}$.

${ }^{6}$ D. Knibbe, Forschungen in Ephesos 9.1.1. (Vienna 1981), especially 95-100.

${ }^{7}$ TAM II 175-6.

${ }^{8}$ For Opramoas see above all TAM II 905.

${ }^{9}$ M. Sartre in A. D. Rizakis (ed.), Roman Onomastics in the Greek East (Athens 1996), 239-50.

${ }^{10}$ For this topic the classic presentation of P. Garnsey, Social Status and Legal Privilege in the Roman Empire (Oxford 1970), esp. ch. 10 remains fundamental.

${ }^{11} \mathrm{CJ}$ 2.11.5. and Dig. 48.19.28.2.
} 
the mines or the fork or to be burned alive; ${ }^{12}$ decurions could not be executed for homicide, with the exception of parricide, according to a ruling of Hadrian; ${ }^{13}$ or again by the Severan period, if not before, it was enshrined in the mandata that provincial governors were obliged to write to the emperor for confirmation of the sentence of relegation if imposed on "decurions or leading citizens". ${ }^{14}$ As Garnsey pointed out, the juristic texts which provide the evidence for such legal privileges do not normaly identify their precise chronological origins nor explicitly explain the reasons for them. However two aspects of these privileges suggest that their bestowal should be seen as purposive rational acts of policy by the Roman state. First, I would stress their normative character. All decurions in all cities in the provinces in principle acquired these privileges which were expected to be upheld by the competent Roman officials. These privileges thus clearly demarcated civic councillors from the mass of the free population of the provinces. Secondly, besides of course the two aristocratc orders of senators and equestrians, there was one other relatively large and homogeneous category of persons who possessed an analogous array of legal privilege, namely veterans. Nobody, I assume, would deny the contention that the legal and other privileges bestowed on veterans were devised as a reward for their essential services to the security and stability of the imperial state. By analogy the legal privileges of local councillors should also be understood as a reward for their services to the imperial state.

\section{Central Rules for the Appointment of Civic Magistrates and Councillors}

In this section I wish to suggest that, although the routine processes of appointing civic magistrates and councillors normally lay in the hands of each community, there is good evidence that throughout the first and second centuries these processes occurred often, if not always, within frameworks laid down by the Roman state.

In the western provinces the widespread dissemination of political constitutions of the Roman type, coloniae and municipia, by definition entailed that rules which, for example, defined eligibility for office, the character of individual magistracies or the size of local councils had been centrally generated. ${ }^{15}$ In the east there is decisive evidence, for some provinces at least, that the Roman state had set normative general frameworks, via the

${ }^{12}$ Dig. 48.19.9.11-12 (a generalisation of Ulpian without explicit reference to any specific imperial decisions).

${ }^{13}$ Dig. 48.19.15.

${ }^{14}$ Dig. 48.19.27.1-2.

${ }^{15}$ The lex Irnitana of course provide a clasic example. 
promulgation of leges provinciae, which regulated the allocation of civic office. In Pontus-Bithynia, as we all know, the lex Pompeia had introduced general rules concerning eligibility for office and membership of local councils. Formal modification of these rules could in principle only occur via the approval of the central power. Thus it was an edict of Augustus which permitted men as young as twenty-two years of age to hold minor magistracies. ${ }^{16}$ We can infer a roughly analogous situation in Lycia-Pamphylia thanks to the publication of the major inscription from Oenoanda which preserves the detailed provisions for the institution of a new quinquennial festival in $125 .{ }^{17}$ In this instance the provision that in future the president of the festival should acquire a five-year period of exemption from other official duties is referred for confirmation to the provincial governor, "since already other governors have given us permision by edicts to grant exemptions from duties to new magistracies which have been created after the codifications of our laws (nomothesiai) just as obtains for the previously existing magistracies." ${ }^{18}$ The nomothesiai in question are almost certainly leges provinciae. It is also possible that similar rules had been introduced in Asia in the late republic via the lex Cornelia. Although we know little of its provisions, the final section of the epigraphic dossier concerning the reform of the Asian calendar in 9 b.c. refers back to the timetable for appointing civic magistrates laid down in "the Cornelian law". 19

Within this context we can also locate the well known practice whereby individual civic communities petitioned the emperor to gain permission to increase the size of their local councils. For example such permission was one of the favours that Dio Chrysostom acquired from Trajan for the city of Prusa; he also implies that Trajan had granted a similar favour to an unnamed city, probably Smyrna, in Asia. ${ }^{20} \mathrm{~A}$ letter of Antoninus Pius to an unknown city, perhaps Parthicopolis, in Macedonia responded to a series of requests concerning the levying of new local taxes, the jurisdictional powers of their magistrates and an increase to 80 in the size of the local council. ${ }^{21}$

\footnotetext{
${ }^{16}$ Plinius Minor, Epistulae 10.78 ; originaly the minimum age had been set at thirty years.

${ }_{17}$ SEG 38, 1462; derived from the magisterial editio princeps of M. Wörrle, Stadt und Fest im kaiserzeitlichen Kleinasien (Munich 1988). My comments in this paragraph are heavily indebted to his analysis, esp. 91-98.

${ }^{18}$ SEG 38, 1462, lines 110-11.

${ }^{19}$ OGIS 458, lines 78-84. It should be emphasised that we do not know whether similar sets of regulations existed for other provinces.

${ }^{20}$ Dio Chrysostom, Orationes 45.3-4 and 7.

${ }^{21}$ J. H. Oliver, Greek Constitutions (Philadelphia 1989), no. 156.
} 
The hypothesis that the Roman state commonly, if not necessarily universally, established the framework of regulations according to which local office was allocated has an additional advantage. For it provides a convincing context for understanding the mass of evidence, especially in the legal sources, of the second and early third centuries about disputes over and appeal from appointment to local civic offices. Normally these disputes and appeals were adjudicated by representatives of the Roman state, especially provincial governors. So Aelius Aristides, as his convoluted acount of his attempts to gain full exemption from civic duties shows, merely took it for granted that, on each occasion he was appointed, his recourse was to appeal to the incumbent proconsul of Asia. ${ }^{22}$

\section{Taxation and Order: dekaprotoi and eirenarchs}

Civic communities played a key intermediary role between state and subject in facilitating the collection of direct taxes and the maintenance of order. In this section I examine the extent to which functionally specific local offices, namely dekaprotoi and eirenarchs, were developed to allow each city to play its intermediary role. My discussion here is limited to the eastern provinces, especially those of Asia-Minor.

First dekaprotoi. In this case there is a standard account in the modern literature. From the late first and early second centuries boards of the first ten men (sometimes as in Lycia of the first twenty) became a common institution in the eastern provinces, especially those of Asia-Minor. They exercised a local financial regulatory role and acquired, also, responsibility for the collection of each city's payment of tribute to Rome. ${ }^{23}$ So D. Magie, writing of the Antonine period, says: "the collection of the taxes paid to Rome, for which the civic authorities were now responsible, was in charge of a board of ten men, composed of the "first" citizens. They are not heard of before the early second century, and in some cities, almost all in Lycia, their number was soon increased to twenty...... The board, as responsible for the payment of the tax levied on a city by the Roman government, appears to have been under obligation to make up any deficit at the members' expense. Other duties of a financial nature might be assigned to them. ${ }^{124}$ Now although it is an attractive

\footnotetext{
${ }^{22}$ For these matters see G. P. Burton, 'Was there a long-term trend to centralisation of authority in the Roman Empire?', Revue de Philologie 72 (1998), 16 ff. with literature.

${ }^{23}$ The earliest attestation of the role of dekaprotos comes from Gerasa in Syria in 66 (IGR III 1376). No examples in Asia-Minor can be dated before the second century.

${ }^{24}$ D. Magie, Roman Rule in Asia-Minor (Princeton 1950), 648 with full citation of earlier literature; for a similar formulation see M. Sartre, L'Orient Romain (Paris 1991), 86.
} 
hypothesis that a civic institution associated with local financial regulation was in the medium-term adapted (whether as a result either of the routinisation of the process of collecting the tribute or of the possible increased burden of Roman demands) into the normal mechanism whereby each city collected its taxes, our direct evidence for this proposition is in fact quite limited. ${ }^{25}$

Legal evidence for the role of dekaproto $i$ is especially meagre; only two extracts of the Digest connect them with the collection of tribute. ${ }^{26}$ One is taken from the Opinions of Ulpian (probably a work of the early fourth century) and merely discusses the minimum age at which a man could be appointed as a dekaprotos. ${ }^{27}$ The second is also taken from a late jurist, Arcadius Charisius, who refers back to a discussion of the late Severan jurist Herennius Modestinus:

The functions of dekaprotoi and eikosaprotoi are of a hybrid nature as Herennius Modestinus determined on excellent grounds. For in collecting taxes (tributa) they both perform a personal service and make good the losses to the imperial treasury on behalf of all the defaulters. ${ }^{28}$

From such an extract it seems to me to be impossible to divine the context of Modestinus' comments, let alone to conclude that boards of the first ten (or twenty) had by the early third century become the standard institutional mechanism for collecting taxes in the cities of the eastern provinces.

The epigraphic evidence is equally problematic. Most epigraphic references merely name the post as part of a local political career. Where clear indication of the duties constitutive of the role of dekaprotoi is given, it mostly concerns local civic financial regulation and supervision. For example in the tariff of Palmyra of 137 the magistrates and dekaprotoi are to oversee the leasing of the tax-contract and its execution. ${ }^{29}$ At Oenoanda in 125 the regulations for the creation of a new quinquennial festival included a provision that the president of the festival had to render accounts to three of the eikosaprotoi in the year after the festival. ${ }^{30}$ In Asia no text explicitly associates them with the collection of the regular tribute, although on one occasion at

\footnotetext{
${ }^{25}$ For other recent brief discussions of the role of dekaprotoi see M. Wörrle, 'Zwei neue griechische Inschriften aus Myra zur Verwaltung Lykiens in der Kaiserzeit', in J. Borchhardt (ed.), Myra: eine lykische Metropole (Berlin 1975), 254 ff. at 290-1; H-J. Horstkotte, Die Theorie vom spatrömische Zwangstaat und das Problem der Steuerhaftung (Munich 1984), $63 \mathrm{ff}$. and F. Quass, Die Honoratiorenschicht in den Städten des griechischen Ostens (Stuttgart 1993), $177 \mathrm{f}$.

${ }^{26}$ So Dig. 50.12.10. concerns the protection of income from an endowment.

${ }^{27}$ Dig. 50.4.3.10-11.

${ }^{28}$ Dig. 50.4.18.26. The final word of the extract may be "deceased" (defunctorum rather than desertorum).

${ }^{29}$ CIS II 3913.

${ }^{30}$ SEG 38, 1462.
} 
Thyateira they are associated with the exaction of a special levy connected to fighting against the Bastarnae. ${ }^{31}$ The epigraphic evidence for the geographic spread of the office in Asia is also limited. Fewer than fifty examples are known; of these over one-third (seventeen) come from the single city of Thyateira where it is epigraphically the best attested office. At Ephesus only four examples are known, one associated with the finances of the temple of Artemis. ${ }^{32}$ In total the office is only attested in twelve Asian cities. ${ }^{33}$

In short although the proposition I adumbrated at the beginning of this section is a priori attractive, it is in practice hard to substantiate. It is perhaps more plausible to assert that in the course of the second century a relatively large, but unquantifiable, number of cities in Asia-Minor developed the institution of boards of the first ten or twenty who both exercised an oversight over civic finances and came to be responsible for the collection of tribute. But this was not a universal phenomenon. Many cities probably continued to mediate their fiscal obligations to the Roman state through pre-existing civic institutional structures. ${ }^{34}$

Secondly eirenarchs. They, like dekaprotoi, were an institutional innovation of the imperial period. They performed a key intermediary role in the maintenance of order through their responsibility both for the hunting down of serious criminals, especially robbers and brigands, in the territory of their city and for the subsequent despatch of such criminals to the provincial governor's tribunal. ${ }^{35}$ Two aspects of this role gave it a very distinctive quality in comparison with all the other civic duties which local notables might perform. First, at least by the reign of Hadrian, detailed instructions, concerning eirenarchs' exercise of their responsibilities, were laid down in the imperial mandata issued to provincial governors. In 135 Antoninus Pius, as proconsul of Asia, published in his provincial edict a chapter of his mandata which prescribed that "eirenarchs, when they had arrested robbers, should question

${ }^{31}$ TAM V, 2, 982. Elsewhere in Asia-Minor an inscription from Iotape may associate them with the exaction of tribute, but the identification is based on conjectural restoration; see the incisive discussion of L. Robert, Documents de l'Asie-Mineure méridionale (Paris 1966), $74 \mathrm{ff}$. In a new inscription from a village in Lycia a single eikosaprotos is responsible for the supervision of a corn tax which may be of an imperial rather than local character; for this document see M. Wörrle \& W. W. Wurster, 'Dereköy: Eine befestigte Siedlung im nordwestlichen Lykien und die Reform ihres dörflichen Zeuskultes', Chiron 27 (1997), $393 \mathrm{ff}$.

${ }^{32}$ Inscr. Ephes III 802; SEG 34, 1093, 1103 and 1107.

33 Namely Acmonia, Apamea, Ephesus, Hieroceaserea, Hierapolis, Iasos, Laodicea ad Lycum, Philadelphia, Smyrna, Stratonicea, Thyateira and Tralles.

${ }^{34} \mathrm{My}$ hesitant comments reflect our seriously defective understanding of the details of the procedures whereby Roman taxes were assessed and levied in the provinces; see best Brunt 1990, op.cit. (n.2), 324 ff.

${ }^{35}$ On eirenarchs see only Magie 1950, op.cit. (n.24), 647 with extensive citation of literature. 
them about their associates and those who harbored them, include reports of their interrogations in letters, seal them and send for the attention of the magistrate [i.e. the governor]." ${ }^{36}$ Secondly, their appointment, in contrast to all other civic offices, was at first instance under the control of the provincial governor. According to Aelius Aristides: "in those times [c.150] the names of the first ten men were sent from each city each year to the governor. The governor had to examine them and appoint one, whomever he approved, from each group as guardian of the peace. ${ }^{137}$

In short the creation of the office of eirenarch, its distinctive method of appointment and the centrally generated regulations for the exercise of the office all provide a striking example of the impact of the imperial state and its demands on the role of civic elites in the provinces.

\section{Central Authority and Local Authority}

This final section attempts to provide a brief overview of the impact of the imperial state and its agents on the primordial local administrative and political role of civic magistrates and councillors who were responsible, for example, for the enactment of locally binding rules, the allocation of local resources and the management and delivery of administrative services. ${ }^{38}$ Within this context through the first two centuries stability of practice, rather than any long-term trend to greater normative central control, was the defining feature of the relationship between the imperial state and the local authorities. Schematically I envisage three main functional principles to have operated.

First, there were always some centraly generated restrictions on the freedom of action of the local authorities. We have already noted the existence of central rules which circumscribed the procedures by which local offices were allocated. Additionally the right of civic authorities to raise new local taxes was always centrally regulated. ${ }^{39}$ The relevant rules are most clearly enunciated in legal sources of the Severan period. So a constitution of Severus and Caracalla stated:

\footnotetext{
${ }^{36}$ Dig. 48.3.6.1.

${ }^{37}$ Orationes 50.72. Without Aristides' testimony nothing in the epigraphic record of Asia-Minor would have allowed us to infer this unusual method of appointment; the chronological origins of this procedure are also unknown.

${ }^{38}$ For good accounts of the nexus of central and local relations see F. Jacques, Le privilege de Liberté (Rome 1984); D. Nörr, Imperium und Polis in der höhen Prinzipatszeit (Munich 1969, 2nd ed.), esp. ch.3 and A.H.M. Jones, The Greek City (Oxford 1940), esp. ch.8.

${ }^{39}$ For what follows see Burton 1998, op.cit. (n.22), 10-13 with literature.
} 
The exaction of new taxes should not be granted lightly; but if your home state is so weak in resources that it needs to be helped by extraordinary aid, present to the governor of the province the facts that you have gathered into this petition. That man after careful investigation of the situation and consideration of the common interest will report to us what he has discovered. We will then judge whether and to what extent your account should be accepted. $^{40}$

Although these procedures have often been claimed as an innovation of the Severan period, none of the legal texts explicitly support such a proposition. Indeed such procedures can be clearly parallelled in the first and second centuries, as requests from Sabora in Baetica to Vespasian and Parthicopolis in Macedonia to Antoninus Pius show. ${ }^{41}$ Furthermore there are no known examples of cities levying new local taxes without authorisation by the imperial state and its agents. It is therefore attractive to hypothesize that from the very beginning of the principate legislation had been enacted to limit the tax-raising powers of provincial cities and, thus, to constrain the effective powers of their local authorities.

My second functional principle is that normally, with the exception of certain categories of privileged (e.g. free) cities, provincial governors possessed the discretionary right, whether at their own initiative or at the request of interested parties, to intervene in and regulate the financial administration of provincial cities. So any governor could examine personally the the public accounts of a city he visited, as the combined testimony of Dio Chrysostom and Pliny illustrate for Pontus-Bithynia at the beginning of the second century ${ }^{42}$ However this discretionary power of intervention never developed into a normative system whereby civic accounts were routinely audited by provincial governors; nor were civic authorities ever expected to furnish the agents of the imperial state with annual accounts of their public revenues and expenditure. So it was wholly exceptional in 177 when, during a senatorial debate on the limitation of the costs of providing gladiatorial shows in the cities of the empire, a senator proposed that provincial governors and other officials throughout the empire should examine the relevant public and private accounts of the previous ten years. On the basis of this systematic investigation an

\footnotetext{
${ }^{40}$ CJ 4.62.1; c.f. 4.62.2-3. and Dig. 39.4.10.3.

${ }^{41}$ Sabora: ILS 6092 (its existing local taxes had been granted by Augustus); Parthicopolis: Oliver 1989, op.cit. (n.21).

${ }^{42}$ Dio Chrysostom, Orationes 48.1-9 and Plinius Minor, Epistulae 10.47-8 with the comments of G. P. Burton, 'Proconsuls, Assizes and the Administration of Justice under the Empire', Journal of Roman Studies 65 (1975), 104.
} 
appropriate scale of prices was to be set. ${ }^{43}$ In normal circumstances such detailed financial information was not as a matter of course available to the imperial state.

My third functional principle is that, excepting the issues discussed above, civic magistrates and councillors routinely exercised a wide-ranging de facto autonomous control over their purely local administrative and political responsibilities. For example they possessed thoughout the first and second centuries the right to enact regulations, which were binding on the inhabitants of their city and territory, without the need of recourse to the Roman authorities for approval or confirmation. ${ }^{44}$ The main impact of the imperial state and its agents was in this context not to constrain, but rather to reinforce and underpin through the superior coercive sanctions at their disposal the actions and decisions of local magistrates and councillors. Although the contextual background for the intervention by provincial governors in matters of local administration is often difficult to reconstruct, such intervention should normally be understood as a response to requests from the local authorities for aid and/or reinforcement. Three examples, all taken from the provinces of Asia-Minor, will suffice to illustrate this pattern of relationship.

My first example originates from the colony of Pisidian Antioch in Galatia during the early nineties and concerns a key routine resonsibility of the local authorities, namely the maintenance of supplies of grain. Because of serious shortages prices had escalated. The duovirs and councillors of the colony therefore wrote to the provincial governor to request help. In response he issued an edict which inter alia ordered all citizens and resident aliens to make declarations of their resources before the duovirs and set a maximum price for the sale of grain. His edict was explicitly underpinned by the threat of penalties against those who failed to obey ${ }^{45}$

My second example originates from Ephesus, the first city of the province of Asia. In the middle of the second century, probably 148/9, the local authorities found themselves unable to enforce effectively harbour regulations

\footnotetext{
${ }^{43}$ J. H. Oliver and R. E. A. Palmer, 'Minutes of an act of the Roman Senate', Hesperia 24 (1955), $320 \mathrm{ff}$. especialy lines $47-55$.

${ }^{44}$ See only Nörr 1969, op.cit. (n.38), 23; for the contingent reasons why occasionally, but not prescriptively, the institution of new civic endowments and their attendant regulations were forwarded for approval or confirmation to the Roman authorities see the excellent discussion of P. Herrmann, 'Kaiserliche Garantie für private Stiftungen', in W. Eck, H. Galsterer and H. Wolff (edd.), Studien zur antiken Sozialgeschichte (Cologne 1980), $339 \mathrm{ff}$.

${ }^{45}$ AE 1925, 126; on this famous document now see the systematic discussion of H-U. Wiemer, 'Das Edikt des L. Antonius Rusticus: eine Preisregulierung als Antwort auf eine überregionale Versorgunskrise', Anatolian Studies 47 (1997), 195 ff.
} 
which were designed to protect access to the quayside. Consequently the proconsul, L. Antonius Albus issued an edict which forbad importers of wood from placing timber on the quayside and importers of stone from sawing their stone there. To enforce his decisions he also warned that in future individuals who contravened his edict would not only pay a fine to the city, but also have to render account of their disobedience at his tribunal. ${ }^{46}$

My third brief example originates from the free city of Aphrodisias during the reign of Commodus. Throughout the first and second centuries Aphrodisias possessed extensive privileges which included exemption from visits by proconsuls. However in 189 they specifically requested the emperor that the proconsul of Asia should visit and examine their "public affairs" (by context certainly matters of financial administration). ${ }^{47}$ Analogously it seems almost certain that appointments of curatores rei publicae to Aphrodisias during the late second century were also made at the city's request. ${ }^{48}$

The structural impact of the imperial state on the primordial local administrative and political roles of civic magistrates and councillors was, therefore, both to constrain and underpin their powers. On the one hand the imperial state limited their tax-raising powers and its agents always had the discretionary right to audit and examine civic financial administration. On the other hand the local authorities continued to exercise a wide-ranging political and administrative autonomy; if their authority was challenged, they could request the aid and support of the agents of the imperial state.

\section{Concluding Remarks}

Schematically we can envisage the impact of the imperial state on the political role and status of local magistrates and councillors through the first two centuries as having five principal features. Three of these were structural. First, local magistrates and councillors continued to exercise a practical autonomous power over their cities and inhabitants; occasional intervention by provincial governors or other agents of the imperial state in matters of local administration served functionally to reinforce this power. Secondly, however, there were certain normative limits on this autonomy. Through devices such as municipal charters and leges provinciae the imperial state commonly provided

\footnotetext{
${ }^{46}$ Inscr. Ephes I 23.

47 J. Reynolds, Aphrodisias and Rome (London 1982), no. 16.

${ }^{48}$ See Reynolds 1982, op.cit. (n. 47), 121 and appendix 9; for an excellent discussion of the reasons for the appointment of curatores in general see F. Vittinghoff, 'Zur Entwicklung der städtischen Selbstverwaltung - Einige kritische Anmerkungen' in F. Vittinghoff (ed.), Stadt und Herrschaft: Römische Kaiserzeit und hohes Mittelalter (Munich 1982), 107-146 at $113 \mathrm{ff}$.
} 
the framework within which local office was allocated. Analogously the taxraising powers of each community were strictly controlled. Thirdly, the locally based political power of magistrates and councillors was integrated into the wider imperial political order through the key intermediary role they played in maintaining order and collecting imperial taxes. Across time two further key features emerged. First, local magistrates and councillors acquired generic legal privileges, analogous to those bestowed on veterans, which were elaborated and refined during the second century, although it is impossible for us empirically to define their exact origins. Secondly, the devolution of intermediary responsibility for maintaining order and collecting taxes to the civic authorities promoted, at least in Asia-Minor, institutional innovation in the form of the roles of eirenarch and perhaps, but not certainly or universally, dekaprotos.

In short the imperial state both shaped and underpinned the political role and status of local magistrates and councillors through an historical process which functionally recognised their crucial contribution to the longterm political stability of the empire.

Manchester, September 2000. 